\title{
Relasi Agama, Magi Dan Sains Dalam Pentas Politik: Studi Kasus Bunda - Sang Penasehat Spiritual
}

\author{
Hadisaputra \\ Peneliti Institute for Research and Education (I-READ), Makassar \\ alkemis.institute@gmail.com
}

\begin{abstract}
Modern political institutions that glorifies scientific approaches still open a space for metaphysical ones. In a political competition, science institutionalize itself through political survey and consultant, and metaphysical aspect ispersonified by spiritual counselors.This article focuses on the practices of a political spiritual councelor in South Sulawesi, named Bunda. Thesuccessful of Bunda in her practice as a spiritual counselor in the modern era cannot be separated from her ability to to integrate between religion, magi and science. This is performed by combining between the aspects of religion and magi, such as zikir ritual (zikir mappateppe', zikir hajat, and zikir 'sapu mata'), animal sacrificing, and employing Majelis Zikir and orphasn for the zikir; and science aspect can be seen from the zikir package with measurable operational costs which can be varied depending on the social status of the candidate and the number of votes needed.The costs of zikir package vary, and each has its own consequencewhich is informed to candidate in advance.
\end{abstract}

Key Words: spiritual councelor, candidate, zikir, magi, science, vote, religion.

\section{Pendahuluan}

Berpolitik di era modern mesti pakai sains.

Semua strategi pemenangan, mesti terukur.

Perangkat ilmu pengetahuan modern sudah menyediakan semua instrumen yang dibutuhkan, tandas Choel Mallarangeng, konsultan politik FOX Indonesia.

Tapi masih banyak politisi yang bahkan bertitel Magister dan Doktor tetap suka pergi ke dukun daeng, saya menyela spontan.

Kasihan sekali orang tua kita, kasi sekolah-ki tinggi-tinggi kalau berpolitik pun masih harus pakai dukun, respon Choel sembari menepuk jidatnya.

Demikian salah satu penggalan perbincangan saya dengan Andi Zulkarnaen Mallarangeng. Waktu itu, saya dan beberapa orang kawan dari Makassar memang diutus dan dibiayai oleh salah seorang calon Walikota Makassar untuk belajar marketing politic kepada konsultan politik yang turut menjadi arsitek kemenangan Susilo Bambang Yudoyono pada pemilihan presiden (Pilpres) 2009. Ia pulalah yang menghantar Edi Baskoro Yudoyono sebagai peraih suara terbanyak dari semua anggota DPR-RI yang berhasil lolos ke Senayan dalam Pemilihan Legislatif 2009. Andi Zulkarnaen Mallarangeng adalah representasi konsultan politik yang lahir dari 'rahim' pendidikan modern, dan memandang kontestasi politik dengan kacamata rasionalitas.

Modernitas seringkali dikaitkan dengan kepercayaan terhadap dogma rasionalitas, sedangkan fenomena maraknya politisi yang berkonsultasi ke paranormal sering dipandang sebagai perilaku yang tidak rasional. Kapferer (dalam Alhumami 2009) menjelaskan bahwa kepercayaan kepada dukun dan praktik perdukunan merupakan local beliefs yang terpatri dalam kebudayaan suatu masyarakat. Sebagai local beliefs, lanjut Kapferer, keduanya tak dapat dinilai dari sudut pandang rasionalitas ilmu karena memiliki nalar dan logika sendiri, rationality behind irrationality. Alhumami (2009) menyimpulkan bahwa praktik perdukunan bukan khas masyarakat tribal dan tradisional yang melambangkan keterbelakangan karena 'bangsa maju dan modern di Eropa dan Amerika yang mengagungkan rasionalitas juga memiliki sejarah perdukunan, berwujud santet. Putra (2014:130) mencontohkan bagaimana mantan 
First Lady Amerika Serikat, Nancy Reagan, memiliki pasukan paranormal yang bertugas untuk memberikan konsultasi spiritual terkait tugas Ronald Reagan sebagai Presiden Amerika periode 1980-1988. Adolf Hittler adalah contoh lain, pemimpin Jerman, yang juga memiliki pengetahuan yang luas seputar mitos dan sangat akrab dengan dunia perdukunan.

Kedekatan para pemimpin dunia dengan dunia perdukunan juga terjadi di Indonesia. Adams (2007:184), penulis biografi Soekarno, mengisahkan jimat batu cincin yang dimiliki Bung Karno yang merupakan pemberian dari salah satu pengikut setianya di Bandung yang dengan penuh keyakinan mengatakan bahwa cincin batu tersebut diharapkan akan memberi efek positif dalam kehidupan Soekarno.

Dunia spiritual juga tak terpisahkan dari kehidupan Suharto, Presiden Republik Indonesia kedua. Ia mengakui bahwa sejak muda telah memiliki guru spiritual, salah satunya Pak Darjatmo. Putra (2014:151) menuliskan pernyataan Soeharto:

Bermacam-macam orang datang minta tolong pada Pak Darjatmo, dari mulai yang sakit kulit, sakit panas sampai kepada yang mempersoalkan perkawinan dan perceraia$\mathrm{n}$, yang mendambakan anak, kesulitan dalam berdagang, urusan dengan penguasa, yang merasa kemasukan setan, yang tertimpa oleh pemerasan orang ketiga, dan macam-macam lagi. Dan saya tahu dari dekat, bahwa memang banyak diantara mereka yang meminta tolong itu, kemudian sembuh, setelah mengikuti petunjuk Pak Darjatmo.

Fenomena kekinian yang serupa dapat dirujuk pada headline Tribun Timur (24 Oktober 2013) yang berjudul 'Jimat Maccaleg Rp.10M'. Berita tersebut mengulas sepak terjang paranormal Ki Joko Bodo dalam pemilihan legislatif (Pileg) dan pemilihan presiden (Pilpres). Ki Joko Bodo mengemukakan sejumlah ritual bernuansa sinkretis (seperti berpuasa, pantang minumminuman keras dan pantang berhubungan seksual) yang harus dijalankan kliennya. Biasanya disertai dengan pemberian jimat (seperti keris, batu akik, Al-Qur'an) yang diikuti dengan mandi kembang. Tarif penasehatan spiritual Ki Joko bervariasi berdasarkan kelas pencalonan klien. Caleg DPR-RI, dikenakan tarif antara 1 sampai 10 Milyar, sedangkan calon Presiden, berkisar antara $\$ 1$ juta s.d $\$ 5$ juta (sekitar Rp.11 miliar s.d Rp.60 milliar).

Mantan Wakil Menteri Agama, Nasaruddin Umar menjelaskan bahwa di era reformasi dan globalisasi dewasa ini, ada fenomena makin menguatnya praktik perdukunan menjelang Pemilihan Kepala Daerah. Para dukun menyadari semakin signifikannya fungsi dan peran mereka yang dulu ditutup-tutupi, sekarang dipertontonkan secara terbuka (Haluan 2012). Jika dulu kiprah mereka cenderung ditempatkan di panggung belakang (back stage), kini mereka tampil di panggung depan (front stage) dalam menawarkan jasa (baca Goffman 1959), sebagaimana iklan di Gambar 1 berikut ini.

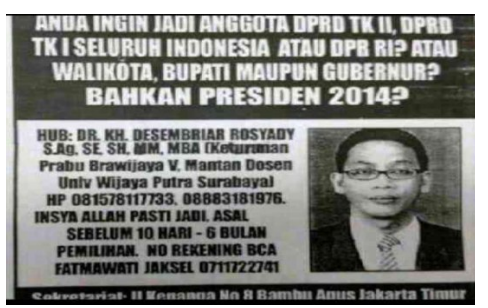

Gambar 1. Contoh Iklan Paranormal (Sumber: Merdeka, 16 September 2013)

Iklan di atas menegaskan bahwa paranormal hadir dengan memaksimalkan modalitas simbolik, dalam bentuk gelar (seperti gelar akademik, gelar keagamaan, gelar bangsawan), fashion (seperti berjas, berdasi dan berkacamata). Penyertaan nomor rekening pada gambar diatas juga menyiratkan profesionalitas: 'ada uang, ada jasa'. Iklan ini menepis kesan bahwa orangorang yang dianggap memiliki kekuatan supranatural adalah mereka yang tidak berpendidikan, berpakaian tradisional, tinggal di kampung dan membantu sesama tanpa pamrih.

Keberadaan penasehat spiritual dalam ranah politik lokal juga masih menunjukkan eksistensinya di Sulawesi Selatan. Hal ini ditunjukkan oleh pemberitaan di media massa lokal menjelang pemilihan legislatif (Pileg) 2014 lalu. Harian Rakyat Sulsel (23 Februari 2014) memuat berita berjudul 'Jasa Paranormal Bayangi Para Caleg' yang mengungkap pengakuan sejumlah caleg bahwa ada penasehat spiritual yang proaktif 
menawarkan jasanya dengan tarif yang bervariasi antara Rp50 juta sampai Rp150 juta. Mekanisme pembayarannya dapat dicicil, disertai surat perjanjian yang menyatakan apabila sang kandidat tidak lolos, uang akan dikembalikan.

Penasehat spiritual politik di Sulawesi Selatan tidak sepenuhnya disandarkan pada ajaran agama Islam. Pelras (2006:216) menyebut masuknya Islam di Sulawesi Selatan menyebabkan terjadinya 'sinkretisme esoteris' dan 'sinkretisme praktis ${ }^{1}$ Perpaduan sistem kepercayaan dalam berbagai ritual keseharian masyarakat tersebut juga mewarnai praktik yang dilakukan oleh penasehat spiritual politik. Studi ini mengeksplorasi keterkaitan antara magi, agama, dan sains dalam aktivitas politik praktis di era modern.

Fenomena kehadiran penasehat spiritual politik telah sering diulas oleh media massa, namun penelitian yang membahas tentang penasehat spiritual dalam kancah politik lokal masih terbatas, kebanyakan kajian hanya seputar praktik perdukunan (Syuhudi 2013, Pelras 2006, Bennett 2005, Said 1996, Geertz 1983). Geertz (1983), misalnya, mengungkapkan bahwa dalam masyarakat tradisional, dukun adalah spesialis magi umum yang berguna untuk mengobati orang sakit, baik fisik maupun psikologis, meramal kejadian masa depan, penemu barangbarang hilang, pemberi jaminan tentang peruntungan yang baik, tidak segan-segan mempraktikkan sihir berdasarkan permintaan klien. Temuan Bennett (2005) di masyarakat Sasak menunjukkan keberdampingan sihir dan Islam. Bennet menemukan orang yang dianggap saleh, tapi sangat percaya dengan takhayul. Agama dan sihir memiliki fungsi masing-masing dalam masyarakat, sehingga tidak saling dipertentangkan. Pelras (2006) juga menggambarkan bahwa ritual pra-Islam juga dapat berdampingan dengan ritual Islam, meskipun proporsinya berbeda

\footnotetext{
${ }^{1}$ Sinkretisme esoteris adalah ajaran aliran kepercayaan terjadi pada periode awal Islamisasi, disebarkan melalui teks-teks yang sebagian besar lisan (meskipun ada pula yang tertulis), berisi ajaran yang mengawinkan sufisme Islam dengan konsep ketuhanan (teologi) dan konsep mengenai alam semesta (kosmologi) pra-Islam Bugis. Sinkretisme praktis yaitu sikap beragama tanpa mementingkan pemahaman ilmu agama (Pelras 2006:219).
}

antara satu ritual dengan ritual yang lain. Ritual tersebut juga dipraktekkan oleh Muslim yang dianggap taat beribadah. Eksistensi pengobatan dukun masih tetap signifikan oleh masyarakat perkotaan seperti Makassar karena mereka mampu beradaptasi dengan lingkungan perkotaan (Said 1996), untuk mempertahankan eksistensi mereka (Syuhudi 2013).

Kajian yang terkait dengan politik lokal, seperti yang dilakukan Roth (2007), Bakti (2007) dan Fahmid (2011) pun belum 'menyentuh' kehadiran penasehat spiritual politik. Roth (2007) menekankan pentingnya pendekatan sosio-historis dan etno-religius dalam studi politik lokal. Bakti (2007) menunjukkan signifikannya peran kaum bangsawan dalam struktur pemerintahan Wajo sejak akhir pemerintahan Orde Baru hingga pemilu 2004. Fahmid (2011) menyorot proses pembentukan elit etnis Bugis dan Makassar, yang terdiri atas empat tahapan, yaitu tradisional, feodalisme, Islam modern, dan sekularisme.

Penelitian yang secara spesifik mengaitkan kiprah paranormal/dukun dengan dunia politik, masih berkisar di Pulau Jawa, seperti studi Sahlan (2010) tentang peran dukun di Banyuwangi. Ia menunjukkan bahwa praktek dukun politik tidak hanya pada aspek batiniah, tapi juga pada aspek lahiriah, seperti menjadi public speaker bagi kandidat yang didukung-nya.

Kontribusi baru dari penelitian ini adalah ulasan seputar latar belakang kehidupan seorang 'penasehat spiritual politik' di Sulawesi Selatan, deskripsi mendalam tentang ritual yang dijalankan, serta linearitas biaya dan konsekuensi dalam praktik penasehat spiritual politik. Dimensi spiritualitas tetap memeroleh tempat tersendiri, ditengah saintifikasi perangkat politik modern. Di satu sisi, para aktor politik semakin 'menuhankan' penggunaan lembaga survei dan konsultan politik. Di sisi lain, praktik penasehat spiritual politik tetap menjadi 'magnet' tersendiri dan semakin menunjukkan signifikasinya.

\footnotetext{
${ }^{2}$ Dalam kajian ini, digunakan istilah 'penasihat spiritual'. Istilah ini pertama kali saya temukan di media massa, disinonimkan dengan istilah paranormal atau dukun, atau predikat yang dilekatkan pada tokoh agama (ustaz) yang sering mendampingi pejabat/politisi. Istilah ini tidak terkesan menghakimi, dan lebih diterima oleh informan.
} 


\section{Metode Penelitian}

Penelitian ini dilakukan di Kabupaten Maros, Sulawesi Selatan. Informan yang diwawancarai adalah Bunda, seorang penasehat spiritual politik yang memiliki kantor yayasan di daerah ini, namun berdomisili di Kota Makassar. Kliennya berasal dari berbagai provinsi dan kabupaten di nusantara, termasuk dari luar Sulawesi Selatan, seperti Kalimantan Timur, Sulawesi Tenggara, dan Jakarta.

Bunda sebagai penasehat spiritual politik, diulas sebagai studi kasus tunggal. Metode ini dipilih untuk menggambarkan praktik penasehatan spiritual yang dilakukan Bunda-dimana ia berpengalaman mendampingi banyak klien di berbagai level kompetisi politik-secara komprehensif.

Pengumpulan data dilakukan dengan mengombinasikan antara wawancara dan pengamatan. Wawancara diarahkan pada eksplorasi latar belakang kehidupan Bunda sebagai penasehat spiritual, seperti latar belakang keluarga, pendidikan dan sumber ilmu supranatural yang dimilikinya, praktik ritual, peralatan yang digunakan serta biaya yang harus dibayar oleh politisi yang didampinginya.

Pengamatan yang dilakukan tak sekedar mengamati, tapi juga mendengarkan yang diistilahkan oleh Idrus (2003) dengan kombinasi 'watching' dan 'listening', yang merupakan kombinasi komplementer untuk 'belajar' dari masyarakat. Objek yang diobservasi meliputi, kantor (termasuk foto-foto klien yang dipajang) dan situasi kantor Bunda (orang-orang yang beraktivitas di kantor Bunda), sikap dan cara bertutur Bunda dalam menjalankan praktiknya.

Analisis data dilakukan dengan mengklasifikasi tema yang muncul dari transkrip wawancara dan laporan observasi. Data diklasifikasikan berdasarkan tema, seperti latar belakang kehidupan Bunda, proses mendapatkan kemampuan supranatural, berbagai jenis zikir yang sering dipraktikkannya, konsekuensi biaya atas ritual yang dijalankannya, serta keterkaitan antara magi, agama dan ritual dalam praktik sebagai penasehat spiritual politik.

Etika penelitian diterapkan dalam mewawancarai Bunda, diawali dengan menjelaskan topik, tujuan dan manfaat penelitian. Setelah Bunda menyatakan kesediaannya dan bersedia direkam selama wawancara berlangsung. Semua informasi yang diberikan dijaga kerahasiaannya (confidential), termasuk identitas informan. Nama klien, dan nama daerah dimana mereka berkompetisi juga tidak dituliskan demi menjunjung prinsip confidential.

\section{Latar Belakang Kehidupan Bunda}

Bunda, perempuan berusia 40 tahun, seorang penasehat spiritual dengan latar pendidikan sarjana (S1), terlahir dari keluarga petani, anak bungsu dari tiga bersaudara, dan hanya dirinya sendiri yang memiliki kemampuan supranatural di dalam keluarganya. Bunda merupakan panggilan akrab dan populer dirinya oleh klien, khususnya di kalangan politisi perkotaan. Bunda menolak dipanggil sanro (dukun), karena istilah itu identik dengan ilmu klenik yang bertentangan dengan agama. Bunda menegaskan bahwa praktek yang ia lakukan bersumber dari ajaran agama. Jika bukan dari ajaran agama, praktek tersebut merupakan tradisi yang sejalan atau tidak bertentangan dengan agama.

Dalam studinya di Mojokuto, Geertz (1983:129) mengungkapkan alasan orang menolak disebut dukun karena istilah ini merujuk pada seseorang yang menerima bayaran. Orangorang yang memiliki kemampuan mengobati lebih senang dipanggil pitulung (pemberi pertolongan) atau orang yang menjanjikan kepastian dalam kaitan dengan kesembuhan.

Meski Bunda tidak ingin disebut dukun (sanro) atau paranormal, namun para klien atau masyarakat sekitar tempat tinggalnya tetap mengenalinya sebagai sanro karena banyaknya pasien yang hilir-mudik di rumah tersebut untuk berobat. Warga memanggil Bunda dengan sebutan puang (panggilan bagi bangsawan Bugis) atau $\mathrm{Bu}$ Aji (baca: $\mathrm{Bu}$ Haji, yang dilekatkan pada perempuan yang telah menunaikan ibadah haji), dan Bunda tidak keberatan dengan panggilan tersebut.

Sikap Bunda yang tidak keberatan dengan panggilan kebangsawanan dan keagamaan menyiratkan pemahaman Bunda tentang penting- 
nya 'modal simbolik', yakni semua bentuk pengakuan oleh kelompok, baik secara institusional maupun non-institusional, yang dapat diperoleh dari jabatan, gelar pendidikan, gelar keagamaan, status kebangsawanan, dll. (Halim 2014:110-111).

Penampilannya Bunda cukup sederhana, menggunakan pakaian muslimah yang biasa dikenakan ibu-ibu Majelis Taklim, jauh dari kesan klenik. Tutur katanya cukup lembut, dengan aksen Bugis yang khas. Suasana santai pun tergambar di kantor tersebut, tak ada resepsionis seperti kantor pada umumnya. Tetangga pun terlihat bebas keluar masuk. Bunda tidak pernah membayangkan dirinya memiliki kemampuan supranatural, sebagaimana dijelaskannya:

Tidak pernah. Saya kan nakal dulu. Kalau mengaji, saya panjat-panjat. Pokoknya, nanti sudah mengaji baru saya turun. Sampai SMA, saya tidak tahu mengaji. Kuliahma tidak tahu juga. Kalau sembahyang kutahuji, macam Al-fatihah. Kalau dibaca tidak kutahu. Adapi begini (kekuatan supranatural), baru saya tahu mengaji (Bunda, 14 April 2014).

Bunda menyebut masa mudanya adalah 'era kenakalan', membaca Al-Qur'an pun ia tak mampu. Kini, bahkan ia telah membuat sendiri buku panduan zikir bagi jamaahnya. Ia juga mengetahui dan menggunakan ayat-ayat khusus yang dianggap ampuh untuk berbagai masalah yang dihadapi, misalnya, tujuh ayat Munjiyat (Surah At-Taubah:51, Surah Yunus:107, Surah Huud:6, Surat Huud:56, Surah Al-Ankabut:60, Surah Al-Faathir:2, serta Surah Az-Zumar:38). Ayat-ayat berfungsi sebagai 'tolak bala', pelindung dari pelbagai bencana, kesulitan dan kesusahan. Bunda sering menganjurkan kliennya untuk membaca ayat-ayat tersebut jika sedang dirundung masalah, baik masalah kesehatan, ekonomi, rumah tangga, maupun untuk terhindar dari berbagai macam bencana.Terjemahan ayatayat diatas, secara umum memang bermakna permohonan untuk terhindar dari bencana dan meminta kelapangan rezeki.

Bunda menjelaskan tentang proses awal ia mendapatkan ilmu supranatural melalui mimpi beberapa kali, dimana ia bertemu dengan seorang tua. Setelahnya, tiba-tiba ia dapat membaca AlQur'an (baca Pelras 2006:224). Jika ia ingin menerawang sesuatu yang belum terjadi, ia mendapatkannya melalui 'petunjuk' melalui mimpi. Setelah kabar tentang Bunda yang mendapatkan kemampuan spiritual melalui mimpi mulai beredar dari mulut ke mulut, ia mulai didatangi oleh banyak orang. Bunda bertutur:

Banyak orang datang, tapi saya-kan tidak tahu. Langsung ambil-ka' tasbih, ambilka' Al-Qur'an. Jadi kalau ada orang bertanya spontan, saya tanyaki (memberitahu). Akhirnya saya buka dzikir. Banyak rakyat kasian. Belum ada pejabat yang tahu. Ada orang lumpuh, ada juga pedagang,dzikir-ji kuajarkan-ki. Banyak (orang datang),biar sekarang kalau saya tinggal di rumah, sampai jam 12 malam, jam 3 malam. Bukan praktek, tapi tidak berhenti orang datang. Kalau dia tahu adaka langsung datang (Bunda, 14 April 2014).

Bunda didatangi banyak orang untuk berkonsultasi tentang beragam hal, mulai dari seputar penyakit (misalnya, kelumpuhan, kanker), permintaan kelancaran rezeki, mengungkap pelaku tindak kriminal, mencegah malapetaka, mencegah seseorang menjadi tersangka, sampai menjadi penasehat politik. Penasehat politik baru mulai dipraktekkan sejak Bunda mendapatkan 'mimpi' tentang Bupati yang akan memimpin di daerah asalnya.

Salah satu kisah yang diceritakan oleh Bunda yang menunjukkan kapasitasnya dalam praktek pengobatan adalah seorang pasien kanker dari Brunei Darussalam yang sudah berobat pada 30 rumah sakit yang berbeda, namun akhirnya dapat disembuhkan oleh Bunda dengan keampuhan metode zikirnya. Terkait kasus kriminal, Bunda tak berani untuk melakukannya, karena memiliki pengalaman yang membuatnya trauma. Bunda pernah menemukan pelaku pencurian telepon genggam, pelakunya mengelak dan menuduh Bunda telah memfitnahnya. Pelaku yang berperawakan besar dan berambut gonrong itu mendatangi rumah Bunda dengan membawa parang panjang.

Kekuatan spiritual yang dimiliki Bunda juga diklaim pernah mencegah terjadinya kecelakaan pesawat. Bunda menjelaskan suatu peristiwa 
ketika ia bertolak dari Jakarta menuju Makassar. Sebelum pesawat take off, Bunda telah memperingatkan petugas maskapai, bahwa pesawat yang akan diterbangkan mengalami kerusakan. Sayangnya peringatan Bunda tidak digubris, pesawat tetap diterbangkan dengan membawa ratusan penumpang, ditengah perjalanan, mesin pesawat rusak, tak dapat lagi melanjutkan penerbangan. Bunda mengklaim bahwa ia menggunakan tenaga dalamnya agar pesawat tetap dapat terbang kembali ke Jakarta. Bunda mengalami kelumpuhan saat pesawat mendarat, karena menurutnya ia telah mengeluarkan hampir seluruh energinya untuk menyelamatkan pesawat tersebut. Maskapai pesawat yang ia selamatkan memberikan asuransi khusus kepadanya, khawatir kelumpuhan yang dialami Bunda akan berlangsung seumur hidup. Peran Bunda dalam mencegah jatuhnya pesawat tersebut sempat menghebohkan publik, bahkan ia sempat diwawancarai oleh stasiun televisi saat itu.Setelah kejadian tersebut, Bunda diterbangkan pulang ke Makassar dengan pesawat khusus.

Bunda juga sering membantu mendo'akan sejumlah tersangka kasus korupsi, namun terbatas pada tersangka yang selama ini memang dikenal baik. Tersangka yang dido'akan adalah mereka yang tersangkut kasus korupsi atas kesalahan administratif, bukan karena usaha sengaja memperkaya diri, sebagaimana dinyatakannya berikut ini:

Waktu baru ditangkap itu, tidak pernahmi diungkap-ungkap ini, selama darika sana (bertemu dengan koruptor). Tidak ditarik barangnya. Artinya, ada orang korupsi, ditarik (disita) rumahnya, apanya. Saya datang (ke pengadilan), bagaimana supaya itu wartawan, LSM tidak membesarbesarkan. Biar orang korupsi mau dipenjara, saya dapat bantu. Kalau memang ada hukuman, palingan hukuman ringan (Bunda, 14 April 2014).

Khasiat do'a Bunda untuk kasus korupsi yaitu, jika kasus masih bersifat desas-desus di kalangan wartawan atau aktivis Lembaga Swadaya Masyarakat (LSM), maka kasus tersebut tidak akan dibesar-besarkan. Jika kasus baru pada tahap penyidikan awal, maka penyidik akan sulit bahkan gagal menemukan bukti. Jikapun tetap dinyatakan terbukti bersalah, Bunda dapat mendo'akan agar hukumannya jauh lebih ringan dari tuntutan jaksa. Bunda juga dapat mengamankan agar rumah atau harta berharga lainnya tidak disita oleh pihak berwenang.

Bunda juga memiliki klien dari kalangan akademisi, yang selama ini diidentikan sebagai masyarakat ilmiah yang mendewakan rasionalisme dan empirisme. Sejumlah pemimpin universitas terkemuka di Makassar sering berkonsultasi kepada Bunda. Permintaan sejumlah pemimpin kampus tersebut juga bermacammacam. Ada yang meminta dido'akan agar dapat memenangkan pemilihan pemimpin di kampus, hingga permintaan agar mereka selamat dari jeratan kasus hukum atas sejumlah proyek pembangunan di kampus yang dipimpinnya.

Bunda lebih banyak bersentuhan dengan klien berlatar belakang politisi. Keterlibatan Bunda dalam aktivitas politik dimulai sejak 2004. Saat itu ia mendorong seorang birokrat senior dari salah satu kabupaten di Sulawesi Selatan agar maju dalam pemilihan Bupati. Ini didasarkan terawangannya dimana beliau 'melihat' gambar birokrat senior tersebut menduduki kursi bupati. Bunda lalu mendatanginya untuk menyampaikan bahwa ia harus maju menjadi calon bupati. Awalnya sang birokrat menolak karena ia merasa tidak mungkin menang. Namun, Bunda meyakinkan berdasarkan hasil terawangannya. Birokrat tersebut akhirnya berlaga dalam pemilukada dan menang.

Pengalaman tersebut yang menjadi awal mula Bunda mulai terlibat dalam aktivitas politik praktis. Ia mengklaim, sampai saat ini telah memberikan pendampingan spiritual kepada ratusan politisi. Mulai dari calon anggota legislatif, calon bupati/walikota, baik di Sulawesi Selatan maupun wilayah lainnya, seperti di Sulawesi Tenggara dan Kalimantan Timur, sampai calon gubernur dan calon presiden. Bunda memajang fotonya bersama dengan sejumlah politisi/pejabat yang pernah menjadi klien untuk meyakinkan calon kliennya di kantor yayasan, tempat yang sering ia gunakan menerima klien. 
Proses keterlibatan penasehat spiritual dalam pemerintahan juga diulas Manguelle (2006:123), seorang intelektual dari Benua Afrika, yang menyatakan bahwa ilmu sihir di Afrika sangat menentukan jalannya suatu pemerintahan. Dukun mengelilingi para presiden Afrika, dan tidak ada yang benar-benar penting dalam politik tanpa pertolongan tukang tenung. Dukun-dukun tersebut bertanggung jawab untuk meyakinkan bahwa yang berwenang masih langgeng kekuasaannya dengan mendeteksi dan menetralisir perlawanan yang mungkin ada.

\section{Rangkaian Zikir}

Bunda tidak membebani kliennya untuk melakukan ritual atau membaca do'a tertentu. Ritual sepenuhnya menjadi tanggungjawab Bunda. Ia memiliki seperangkat metode ritual yang diciptakan sendiri, terdiri atas tiga rangkaian, yakni: zikir mappateppe' (memprediksi), zikir hajat (memohon kemenangan), zikir 'sapu mata' (tolak bala penampakan).

\section{Zikir Mappateppe'}

Proses zikir pendahuluan disebut dengan istilah mappateppe, ${ }^{3}$ yang dilakukan dengan mendudukkan seratus orang untuk berzikir selama 3 kali berturut-turut. Tujuannya untuk memeroleh 'petunjuk' apakah sang politisi memiliki peluang terpilih atau tidak, selain untuk menakar apakah perjuangan yang akan dilalui berat atau ringan. 'Petunjuk' akan diterima dengan melihat bayangan sang kandidat melalui mimpi. Semakin jelas bayangan tersebut, berarti peluang sang kandidat untuk menang semakin besar. Proses zikir mappateppe' ini mirip dengan survei pemetaan yang sering dilakukan oleh sejumlah lembaga survei sebelum memutuskan untuk maju atau mendampingi kandidat kepala daerah. Bunda mengungkapkan:

Saya lihat namanya, begini, begini. Kalau ada harapan, kuzikirkan maki dulu. Kalau memang ada bayanganta maju maki terus.

\footnotetext{
${ }^{3}$ Mappateppe adalah kosakata dari Bahasa Bugis, berasal dari akar kata 'teppe' yang artinya percaya. Mappateppe, berarti membuat jadi percaya. Jadi Zikir Mappateppe dimaknai sebagai upaya mempercayai/melihat adanya potensi kemenangan dengan memohon petunjuk kekuatan adikodrati.
}

Kalau tidak ada, nanti saya tanya-ki' dulu. Biar dia bilang bagus surveinya, saya bilang tidak bisa. Atau biar juga rendah hasil surveinya, kalau memang bisa saya bantu, saya bantu (Bunda, 14 April 2014).

Bunda pernah berbeda pendapat dengan hasil yang dirilis sebuah lembaga survei. Seorang caleg yang telah mengantongi hasil survei pernah datang kepadanyadalam keadaan pesimis karena elektabilitas hasil surveinya rendah. Bunda meyakinkannya, bahwa ia akan berhasil mendapatkan kursi ketiga atau keempat di daerah pemilihannya (Dapil). Ternyata prediksi Bunda terbukti, caleg tersebut berhasil menjadi anggota legislatif dan menduduki kursi keempat dari enam kursi yang diperebutkan di Dapilnya.

\section{Zikir Hajat}

Tahapan selanjutnya adalah menjalani ritual mappateppe', Bunda mulai melakukan proses zikir secara rutin untuk pemenuhan hajat sang politisi meraih kursi kepala daerah/anggota legislatif. Adapun bacaan-bacaan zikir yang dibaca dalam zikir bersama, semuanya dirangkum dalam buku zikir yang disusun sendiri olehnya. Buku tersebut dijilid rapi lalu dibagikan kepada para peserta zikir sebelum menjalankan ritual zikir. Pada saat para jamaah zikir membaca buku tersebut, Bunda memberi zikir 'balasan', yaitu lantunan zikir yang dibaca Bunda menyahuti zikir yang dibacakan berjamaah oleh peserta lainnya, yang dilantunkan dalam bahasa Bugis.

Do'a adalah alat komunikasi yang diucapkan oleh manusia untuk berdialog dengan Sang Ilahi atau sesuatu yang bersifat supranatural. Pengalaman berkomunikasi dengan 'sesuatu yang gaib' merupakan pengalaman yang berbeda-beda bagi setiap orang. Terkadang ritual do'a menciptakan atmosfer 'perjumpaan dengan yang gaib' yang dianggap begitu sulit, bahkan banyak orang yang merasa tidak dapat melakukan hubungan langsung dengan yang gaib. Mereka membutuhkan bantuan atau media perantara do'a yang biasanya diperankan oleh orang yang dianggap tokoh suci atau tokoh spiritual seperti penasehat spiritual,dengan tujuan untuk memfasilitasi do'a. 
Keberhasilan do'a sering dikaitkan dengan ketepatan formulasi do'a yang diucapkan, baik dalam urutan do'a maupun banyaknya do'a. Jika bahasa keseharian dituturkan dengan memerhatikan efektifitas dan diksi yang disesuaikan dengan siapa lawan bicara yang dijumpai oleh si penutur, maka 'bahasa agama' ${ }^{4}$ justru sudah dikonstruksi oleh 'yang diajak bicara', atau oleh seseorang yang secara kolektif dianggap manusia pilihan, yang telah diajarkan bagaimana penggunaan bahasa agama oleh manusia (Solihat 2012:69-70).

Bunda juga menyusun formulasi do'a dalam menjalankan ritualnya. Do'a-do'a yang dianggap mampu memuluskan hajat, yaitu; Yasin Fadhilah (surah Yasin dengan model pembacaan yang khas, disertai sejumlah do'a tambahan). Setelah itu, dibacakan Tujuh Ayat Munjiyat, ${ }^{5}$ lalu dilanjutkan dengan pembacaan 'Ayat Kursi' dan pembacaan Shalawat Nariyyah Tafrijiyyah. ${ }^{6}$ Tahap selanjutnya adalah membacakan do'a 'tolak bala' sebagaido'a memohon ampunan untuk kedua orang tua karena Bunda percaya bahwa ridha Allah bergantung kepada keridhaan orang tua, dan murka Allah bergantung kepada kemurkaan orang tua.

\footnotetext{
${ }^{4}$ Bahasa Agama dimaknai sebagai bahasa yang dibuat oleh 'Tuhan' dan atau Pemimpin Agama/Nabi, untuk memudahkan umat berkomunikasi dengan mereka. Dalam Islam, bahasa agama dimaknai sebagai ungkapan-ungkapan yang dikutip dari Quran atau Hadist, untuk berdoa kepada Allah swt.

${ }^{5}$ Ayat Munjiyat (keselamatan) merupakan gabungan dari 7 ayat Al-Quran yang dapat dijadikan sebagai ikhtiar untuk penjagaan keselamatan diri dan pelindung dari berbagai kesulitan, kesusahan dan melepaskan diri dari berbagai permasalahan, termasuk gangguan makhluk halus serta sebagai penawar berbagai jenis penyakit jasmani dan rohani. Tujuh Ayat Munjiyat, yaitu Surah At-Taubah ayat 51, Surah Yunus ayat 107, Surah Huud ayat 6, Surat Huud ayat 56, Surah Al-Ankabut ayat 60 , Surah Al-Faathir ayat 2, serta surrah Az-Zumar ayat 38.

${ }^{6}$ Shalawat Nariyyah Tafrijiyyah yang dianggap ampuh untuk memuluskan hajat. Terjemahan lafaz salawat sebagaimana yang termuat di buku zikir Bunda: 'Ya Allah, limpahkanlah rahmat dan salam yang sempurna kepada penghulu kami Nabi Muhammad, yang lantaran beliau semua yang sulit menjadi mudah, semua yang menyusahkan menjadi terlepas, semua hajat terpenuhi, semua keinginan tercapai dan husnul khatimah (mendapat akhir hidup yang baik), dan lantaran beliau yang mulia siraman hujan dimohon, dan juga kepada keluarga beliau dan sahabatsahabatnya, di setiap saat dan hembusan nafas, sebanyak bilangan setiap yang Engkau tahu'.
}

Rangkaian do'a selanjutnya adalah membaca Istighfar yang diikutidengan Shalawat Badar. ${ }^{7}$ Menurut Bunda, Salawat Badar adalah pujian-pujian kepada Rasulullah SAW dan Ahli Badar (para sahabat Nabi yang mati syahid dalam perang Badar), berbentuk syair, dan dinyanyikan dengan lagu khas yang bermanfaat untuk memohon keselamatan, untuk menghilangkan semua kesusahan, kesempitan dan segala yang menyakitkan; selamat dari bahaya musuh; untuk menangkis orang yang berbuat kemaksiatan dan kerusakan, untuk memperoleh ampunan Allah, dihindarkan dari marabahaya dan bencana, memohon keluasan rezeki, serta mendapatkan keberkahan. Lalu membaca sejumlah surah-surah pendek (seperti, Surah AlFatihah, Surah An-Nashr, Surah Al-Ikhlas, Surah Al-Falaq, dan Surah An-Naas), lalu membaca Asmaul Husna (99 nama Allah), dan ditutup dengan membaca, 'Yaa Allah, Yaa Allah, Yaa Allah, Yaa Allah, Yaa Allah. Amiin Yaa Arhamarraahimiin. Amiin Yaa Rabbal Alamiin'. Bunda menjekankan sistematika do'a tersebut disusun berdasarkan petunjuk yang diperolehnya

\footnotetext{
${ }^{7}$ Naskah Salawat Badar:

Shalaatullaah Salaamul laah 'Alaa Thaaha Rasuulillaah Shalaatullaah Salaamullah 'Alaa Yaa Siin Habiibillaah Tawassalnaa Bibismi llaah Wabil Haadi Rasuulillaah Wakulli Mujaahidin Lillaah Bi Ahlil Badri Yaa Allaah llaahi Sallimil Ummah Minal Aafaati Wanniqmah Wamin Hammin Wamin Ghummah Bi Ahlil Badri Yaa Allaah

Ilaahi Najjinaa Waksyif Jamii'a Adziyyatin Wahrif Makaa idal 'idaa wal thuf Bi Ahlil Badri Yaa Allaah llaahi Naffisil Kurbaa Minal'Ashiina Wal'Athbaa Wakulli Baliyyatin Wawabaa Bi Ahlil Badri Yaa Allaah Wakam Min Rahmatin Washalat Wakam Min Dzillatin Fashalat

Wakam Min Ni'matin Washalat Bi Ahlil Bailri Yaa Allaah Wakam Aghnaita Dzal 'Umri Wakam Autaita D'Zal Faqri Wakam'Aafaita Dzal Wizri Bi Ahlil Badri Yaa Allaah Laqad Dlaaqat'Alal Oalbi Jamii 'ul Ardli Ma' Rahbi Fa Anji Minal Balaas Sha'bi Bi Ahlil Badri Yaa A,llaah Atainaa Thaalibir Rifdi Wajullil Khairi Was Sa'di Fawassi' Minhatal Aidii Bi Ahlil Badri Yaa Allaah Falaa Tardud Ma'al Khaibah Balij'Alnaa'Alath Thaibah Ayaa Dzal 'lzzi Wal Haibah Bi Ahlil Badri Yaa Allaah Wain Tardud Faman Ya-Tii Binaili Jamii'i Haajaati Ayaa jalail mulimmaati Bi Ahlil Badri Yaa Allaah llaahighfir Wa Akrimnaa Binaili Mathaalibin Minnaa Wadaf i Masaa-Atin 'Annaa Bi Ahlil Badri Yaa Allaah llaahii Anta Dzuu Luthfin Wadzuu Fadl-Lin Wadzuu 'Athfin Wakam Min Kurbatin Tanfii Bi Ahlil Badri Yaa Allaah Washalli 'Alan Nabil Barri Bilaa 'Addin Walaa Hashri Wa Aali Saadatin Ghurri Bi Ahlil Badri Yaa Allaah
} 
melalui mimpi. Ia mengklaim, bahwa kombinasi do'a dan zikir tersebut adalah hasil kreasinya sendiri.

Bunda juga sering membaca barzanji $i^{8}$ untuk sang klien, proses pembacaan barzanji dapat dilakukan sampai 4 kali setiap hari. Bagi masyarakat Bugis, barzanji adalah salah satu ritual yang tak terpisahkan dari sejumlah acara seremonial, seperti perkawinan, aqiqah, upacara memasuki rumah baru, dll. Pada akhir abad ke18 dan awal abad ke-19, pembacaan barzanji merupakan pengganti pembacaan naskah-naskah La-Galigo dalam upacara-upacara syukuran (Pelras 1996:224), dan merupakan strategi dakwah yang dikembangkan oleh para pembawa Islam ke jazirah Sulawesi.

\section{Zikir 'Sapu Mata'}

Fase terakhir dari rangkaian zikir adalah zikir 'sapu mata' atau 'tolak bala penampakan' (penerawangan). Zikir jenis ini biasanya hanya digunakan oleh calon presiden atau calon kepala daerah. Belum pernah ada caleg yang memanfaatkan jasa ini karena biayanya yang tergolong mahal. Ini karena biaya penerawangan yang dilakukan Bunda cukup tinggi (Rp 77 juta), yang mencakup biaya konsumsi (termasuk di dalamnya pembelian 100 ekor ayam sebagai syarat) dan biaya operasional pelak-sanaan zikir dan barzanji.

Bunda mengelak jika ritual yang ia lakukan adalah hasil ciptaannya sendiri, tapi sebagai bagian dari budaya lokal. Pengakuan ini sebagai bentuk legitimasi bahwa bunda tidak mengabaikan budaya lokal dalam praktek penasehatan spiritualnya. Dalam tradisi masyarakat Bugis, ketika seorang anak berhasil menamatkan AlQur'an, orang tuanya harus menyembelih (maccéra') beberapa ekor ayam. Tujuannya agar mendapatkan berkah (mabbarakka'). Demikian pula semua do'a yang dipanjatkan Bunda yang disertai dengan berkurban. Misalnya, jika membaca 99 Asmaul Husna (nama-nama Allah), maka ia berkurban 99 ekor ayam agar mendapat-

\footnotetext{
${ }^{8}$ Barzanji adalah kisah sejarah Nabi Muhammad saw, yang ditulis di zaman Khalifah Salahuddin al-Ayyubi sebagai syair penyemangat dalam Perang Salib. Namun pada masyarakat Bugis, pembacaan Barzanji dianggap sebagai 'ritual wajib' dalam berbagai prosesi syukuran.
}

kan berkah sesuai dengan nama dan sifat Allah tersebut. Ardhianto (2012:119) menjelaskan dalam ritual pengorbanan, subyek atau benda/ binatang yang dipersembahkan mendekatkan yang sakral kepada keseharian, sementara subyek/benda-benda keseharian mendekatkan satu sama lain menjadi sakral.

Praktik yang dilakukan Bunda tersebut juga mengonfirmasi temuan Pelras (2006:223), bahwa salah satu contoh ritual pra-Islam yang masih berlangsung hingga kini adalah pengurapan dengan darah (maccera') ayam atau binatang kurban lainnya, seperti kambing. Ritual ini dilakukan kepada seseorang atau terhadap sebuah benda keramat (sacred). Tujuannya untuk memasukkan atau meningkatkan energi vital (sumange'). Bedanya setelah masuknya Islam, proses penyembelihan didahului dengan ucapan bismillah. Ritual maccera' ini dibedakan dengan ritual ibadah kurban yang biasa dilakukan orang Islam pada hari raya Idul Adha.

Pemaknaan terhadap ritual kurban, menurut Pritchard (1940:18) dianggap sebagai percakapan dan ritual antara yang 'terlihat' (manusia) dan yang tak 'terlihat' (Tuhan), melalui sesembahan simbolik. Gagasan utama dari ritual kurban adalah meleburnya dua subyek 'manusia dan Tuhan' ke dalam sebuah realitas ritual perjamuan dan pertukaran.

Bunda memberikan contoh ritual 'sapu mata' ini dengan memperlihatkan rekaman video ritual yang tersimpan di telepon genggamnya, yang merupakan ritual untuk melihat peluang salah satu capres dalam pemilihan presiden (Pilpres) tahun 2009 lalu. Rekaman tersebut menunjukkan sejumlah perlengkapan ritual, yaitu baskom yang berisi beras ketan, di atas baskom diletakkan buah pala, dua kemenyan arab, buah kelapa bertunas yang sudah dikupas kulit luarnya, serta dua lilin. Semua itu merupakan benda-benda yang memediasi komunikasi antara Bunda dan 'dunia atas'. Beras ketan sebagai makanan bagi dunia arwah, pala dianggap sebagai representasi 'penyedap rasa' dalam sajian ritual 'sapu mata'; kemenyan berfungsi sebagai wewangian agar menyenangkan hati 'yang dimintai pertolongan', semacam persembahan kepada yang gaib (seperti Tuhan, 
Malaikat, Dewa, Jin); kelapa bertunas menandakan harapan terhadap masa depan;dan lilin bermakna sebagai 'penerang jalan' dalam menggapai tujuan.

Rekaman tersebut menunjukkanproses zikir dari sejumlah orang yang dipimpin oleh Bunda. Semakin keras zikir dibacakan, semakin tampak bayangan pada kelapa bertunas yang diletakkan di atas beras dalam baskom tersebut. Ini menandakan bahwa sang kandidat akan memenangi pertarungan. Bunda menjelaskan:

Caraku ini, bukan untuk dipamerkan. Tidak. Karena lamami tinggal (tersimpan) ini. Kita lihat $m i$, ada itu mukanya Pak capres di ini kelapa. Tambah lama, kelihatan mukanya pak capres (yang akan menang). Ada itu mukanya di belakang, dek. Kita lihat mi? Ini mukanya pak capres. Lihat $k i$ tambah lama, tambah kelihatan mukanya pak capres. Jadi zikir $m i$ orang, tambah lama, tambah kelihatan (wajah capres yang akan menang) (Bunda, 14 April 2014).

Pertunjukan tersebut cukup mengesankan. Penampakan bayangan calon presiden yang akan menjadi pemenang dalam Pilpres 2009 muncul dalam 'layar' kelapa bertunas. Bayangan tersebut sangat menyerupai gambar Soesilo Bambang Yudhoyono, sang pemenang Pilpres kala itu.

Bunda menunjukkan lagi beberapa rekaman video ritual (yang ditolak untuk dibagi) terkait penerawangan calon gubernur di beberapa provinsi. Penampakan yang kelihatan pada kelapa dalam baskom tersebut sangat menyerupai orangnya. Rekaman pertunjukan Bunda tersebut membenarkan pernyataan Eriksen (2009:378), bahwa tidak mudah membedakan secara tegas antara pementasan teatrikal dengan pementasan ritual. Ritual 'sapu mata' Bunda adalah ritual yang teatrikal, menarik untuk ditonton, namun tak kehilangan dimensi kesakralannya.

\section{Peserta Zikir, Biaya Ritual, dan \\ Konsekuensinya}

Dalam melantunkan do'a-do'a zikirnya, Bunda tidak sendirian. Ia ditemani oleh ibu-ibu anggota Majelis Zikir yang dibinanya dan sejumlah anak yatim. Bunda menekankan bahwa yang terpenting adalah 'kebersihan hati' peserta zikir. Peserta yang 'kotor hatinya', diukur berdasarkan mendukung-tidaknya ibu-ibu anggota Majelis Zikir terhadap kandidat klien Bunda, sehingga tercipta dualisme 'mendukung-bersih' dan 'tidak mendukung-kotor'.

Bunda menegaskan sejak awal tentang pilihan anggota Majelis Zikir. Ibu-ibu anggota Majelis Zikir yang memiliki pilihan yang berbeda dari kandidat klien Bunda diminta untuk tidak terlibat dalam zikir karena orang tersebut tidak saja dianggap penghianat (atas dirinya dan orang yang dido'akan) tapi juga karena dianggap dapat memengaruhi 'keampuhan' zikir tersebut. Berikut pernyataan Bunda:

Kalau tidak mau kau tusuk, jangan ko datang, penghianat $k o$ itu. Seperti seumpamanya pemilihan Gubernur, pemilihan Walikota. Saya itu, ini kuzikirkan, kalau tidak mau ko tusuk ini, jangan ko datang. Jangan mako datang zikirkan orang, karena salah do'a ko. Kau hianati dirimu (Bunda, 14 April 2014).

Penegasan tersebut menunjukkan Bunda menghargai keterbukaan ketimbang kemunafikan (berzikir tapi tidak mendukung). Namun, jika membandingkan peserta zikir, Bunda jauh lebih mengandalkan 'keampuhan' zikir dari kalangan anak yatim (yang merupakan 'peserta wajib' dalam setiap ritual zikirnya). Bunda percaya bahwa jika satu anak yatim diberi makan, maka 40 malaikat akan mencarikan jalan kebaikan untuk si 'pemberi makan', dan Bunda yakin bahwa anak yatim pasti akan mendo'akan kebaikan untuk orang yang memberikan makanan, sebagaimana keyakinannya atas 'keampuhan' do'a anak yatim.

Bunda bekerja dengan target terukur berdasarkan jumlah suara yang dibutuhkan untuk memenangkan suatu kompetisi politik, sehingga tuntutan biaya juga terukur. Bunda menegaskan dengan analogi bahwa jika memancing dengan 'umpan kecil', pasti ikannya juga akan 'kecil'. Seorang caleg DPRD Provinsi, misalnya, target suaranya 30.000 sampai 50.000 suara, sementara caleg DPRD Kabupaten/Kota target suaranya hanya berkisar antara 3.000 sampai 5.000 suara. 
Target suara inilah yang menentukan biaya ritual.

Terkait biaya ritual, Bunda tak menyebut tarif mutlak. Ritual Bunda yang terdiri atas tiga tahapan (zikir mappateppe, zikir hajat, dan zikir sapu mata), memiliki biaya masing-masing. Zikir mappateppe dilakukan oleh 100 peserta, selama 3 kali. Jika biaya konsumsi dan 'salam tempel' setiap peserta zikir sebesar Rp 50.000, maka zikir ini membutuhkan anggaran sebesar Rp15.000.000,-.

Biaya 'zikir hajat' (memohon kemenangan) yang berorientasi meningkatkan popularitas dan elektabilitas, ditentukan berdasarkan target suara yang dibutuhkan untuk menang. Bunda memiliki formulasi '1000:250', yang berarti jika seorang calon membutuhkan 1.000 suara, maka harus disiapkan 250 peserta zikir. Jika anggaran konsumsi dan transportasi peserta zikir sebesar Rp50.000,-/orang, maka untuk mendapatkan 1.000 suara, dibutuhkan biaya ritual sebesar Rp.12.500.000,-. Biaya zikir hajat ini akan semakin besar, jika target yang dibutuhkan besar pula.

Selain biaya 'operasional' untuk zikir mappateppe dan zikir hajat, zikir 'sapu mata' memiliki biaya tambahan untuk semakin meyakinkan potensi kemenangan sang kandidat sebesar Rp77 juta sebagaimana dijelaskan pada sessi sebelumnya. Inilah yang menjadi alasan zikir 'sapu mata' hanya dapat 'dipesan' oleh calon 'kelas kakap' (seperti calon presiden dan calon kepala daerah).

Bunda juga mengaku telah memiliki tujuh mobil yang diberikan masing-masing kliennya tanpa meminta. Pemberian tersebut diperoleh ketika beberapa kliennya telah berhasil duduk sebagai kepala daerah. Pemberian itu berkelanjutan secara rutin dari sejumlah klien yang telah dan masih menduduki jabatan, baik di eksekutif maupun legislatif.

Berdasarkan paparan tersebut, relasi antara Bunda dengan kliennya dapat dilihat dengan pendekatan 'proposisi sukses' dalam Teori Pertukaran yang diperkenalkan Homans (1974: 16). Dalam 'proposisi sukses', makin sering sebuah tindakan memeroleh imbalan, makin besar pula kecenderungan mengulangi tindakan tersebut. Tak heran jika profesi sebagai penasehat spiritual telah dijalani Bunda selama lebih dari satu dekade, sejak tahun 2004 hingga saat ini.

Proses pendampingan spiritual yang dijalankan Bunda tak selamanya berjalan sesuai harapan. Dari sejumlah nama yang disebutkan sebagai klien Bunda, ada beberapa kandidat yang gagal duduk sebagai Kepala Daerah atau Anggota Legislatif. Namun saya tidak mendapatkan akses untuk menjadikan mereka sebagai informan. Bunda mengelak untuk disebut gagal dalam proses kekalahan sejumlah klien tersebut. Menurutnya, sejak awal ia telah memberi gambaran potensi keterpilihan seorang kandidat. Bagi yang tetap ingin maju, Bunda menawarkan paket zikir untuk mendongkrak popularitas dan elektabilitas, dengan konsekuensi biaya yang telah digambarkan sebelumnya.

Besar-kecilnya biaya yang diberikan oleh kandidat bukan tanpa konsekuensi, karena menurutnya perolehan suara juga tergantung pada biaya ritual. Jika biaya yang diberikan kurang dari jumlah yang dibutuhkan, dan perolehan suara juga tidak mencapai target, maka Bunda akan mengingatkan sang kandidat tentang biaya minim yang diberikannya. Bunda mengisahkan, seorang caleg muda pernah meminta dido'akan, namun hanya sekali ia menyerahkan biaya zikir dengan jumlah sekadarnya. Caleg tersebut tidak lolos, namun sang caleg tidak menyalahkan Bunda atas kegagalannya karena tak dapat memenuhi biaya yang dibutuhkan.

\section{Paranormal dalam Pandangan Islam Puritan dan Sinkretis}

Sebanyak $89,40 \%$ masyarakat Sulawesi Selatan beragama Islam (BPS, 2015). Hal tersebut tidak serta merta membuat sistem kepercayaan lokal sebelum masuknya Islam turut punah. Pelras (2006:216) menyebut masuknya Islam menyebabkan terjadinya 'sinkretisme esoteris' dan 'sinkretisme praktis'. Sinkretisme esoteris adalah ajaran aliran kepercayaan terjadi pada periode awal Islamisasi, disebarkan melalui teks-teks yang sebagian besar lisan (meskipun ada pula yang tertulis), berisi ajaran yang 
mengawinkan sufisme Islam dengan konsep ketuhanan (teologi) dan konsep mengenai alam semesta (kosmologi) pra-Islam Bugis. Sinkretisme praktis yaitu sikap beragama tanpa mementingkan pemahaman ilmu agama (Pelras 2006:219), perpaduan sistem kepercayaan dalam berbagai ritual keseharian masyarakat. Sistem kepercayaan tersebutlah yang mewarnai praktik yang dilakukan oleh penasehat spiritual politik di Sulawesi Selatan.

Padahal, jika menggunakan pendekatan puritan dalam memahami Islam, seharusnya paranormal/dukun tidak lagi memiliki tempat dalam sistem kepercayaan masyarakat Sulawesi Selatan. Sikap puritan ini ditunjukkan oleh Wakil Ketua Pimpinan Wilayah Muhammadiyah Sulawesi Selatan K.H. Baharuddin Pagim:

Sesungguhnya mendatangi dukun dan tukang ramal untuk menanyakan sesuatu kepadanya berkaitan dengan sakit, nasib masa depan, atau untuk mengabarkan sesuatu yang gaib seperti barang hilang, dan yang semisalnya tidak diperbolehkan dalam Islam. Hukumnya haram. Apalagi kalau sampai meyakini dan membenar-kan apa yang mereka katakan. Karena sesuatu yang mereka katakan mengenai hal-hal yang gaib itu hanya didasarkan atas perkiraan belaka, atau dengan cara mendatangkan jin, dan meminta tolong kepada jin-jin itu tentang sesuatu yang mereka inginkan. (K.H. Baharuddin Pagim, 18 April 2014).

Pandangan K.H. Baharuddin tersebut merujuk pada beberapa pandangan Al-Qur'an berikut:

Katakanlah, tidak ada seorang pun di langit dan di bumi yang mengetahui perkara yang ghaib kecuali Allah (QS. An-Naml:65).

Katakanlah, 'Aku tidak berkuasa menarik kemanfaatan bagi diriku dan tidak (pula) menolak kemudharatan kecuali yang dikehendaki Allah. Dan sekiranya aku mengetahui perkara yang ghaib, tentulah aku membuat kebajikan sebanyak-banyaknya dan tidak akan ditimpa kejahatan dan aku tidak lain hanyalah pemberi peringatan, dan pembawa berita gembira bagi orang-orang yang beriman (QS. Al-A'raf: 188).
Dan menurut Hadis bahwa Nabi Muhammad saw:

Kunci perkara ghaib itu ada 5 , tidak ada seorang pun yang mengetahuinya melainkan Allah, Tidak ada yang mengetahui (takdir) apa yang di dalam kandungan selain Allah, tidak ada yang mengetahui apa yang akan terjadi esok selain Allah, tidak ada seorang pun yang mengetahui (dengan pasti) kapan hujan akan turun kecuali Allah, dan tidak ada seorang pun yang mengetahui di bumi mana dia akan mati selain Allah, dan tidak ada yang mengetahui kapan terjadinya hari kiamat kecuali Allah (HR. Bukhari).

Ayat Al-Qur'an dan Hadits yang disitir oleh K.H. Baharuddin Pagim diatas menunjukkan bahwa dalam pandangan Islam puritan, kehadiran para-normal dan dukun dianggap bertentangan dengan Islam. Namun, sebagaimana diingatkan Pelras, Islam yang hadir dalam begitu banyak aspek kehidupan orang Bugis memiliki gambaran yang jauh lebih kompleks dalam praktiknya (Pelras 2006:209-210), yang tak dapat dipandang secara hitam putih atau dipisahkan antara Islam dan budaya setempat. Demikian pula praktik yang dilakoni oleh paranormal yang berperan sebagai penasehat spiritual politik, meski mengklaim melandaskan diri pada Islam, tetapi mereka juga tidak menafikan sistem kepercayaan yang telah hadir sebelum kedatangan Islam.

\section{Praktik Bunda: Magi, Agama, dan Sains}

Magi dan agama adalah dua hal yang berbeda. Magi bertujuan mencapai hubungan dengan kekuatan alam untuk kepentingan pribadi, sedangkan agama berusaha menjalin hubungan dengan makhluk-makhluk rohani yang lebih dari sekadar kekuatan impersonal. Agama berorientasi ketundukan (permohonan), sedangkan magi adalah pemaksaan kehendak atau perintah (Malinowski 1948:68; Peursen 1988:50).

Baal (1987:111-112) berpandangan bahwa jika magi dimaknai sebagai 'tindakan-tindakan ritual sederhana yang diarahkan pada suatu efek konkret', maka do'a untuk memohon sesuatu pun merupakan bagian dari magi. Weber (2012:142- 
146) juga menyatakan sulit memisahkan secara tegas antara magi dan agama, jika sekadar menggunakan parameter bahwa magi menggunakan kekuatan yang memaksa kekuatan adikodrati, sedangkan agama mengandalkan permohonan kepada Tuhan. Weber mencontohkan dua unsur ritual dalam agama, seperti do'a dan penyembelihan kurban, sebagaimana yang dilakukan oleh Bunda. Menurut Weber, kedua ritual ini tetap memiliki akar dalam magi, sebab agama pada praktiknya, tetap mengandung sejumlah besar komponen magi.

Meski magi dan agama sulit dibedakan, namun menurut saya tetap dapat dibedakan paling tidak pada aspek tujuan dan kemampuan 'menjual kepastian'. Pada kedua aspek tersebut, praktik yang dilakukan Bunda lebih dekat dengan magi daripada agama. Pada aspek tujuan, zikir yang digelar Bunda berorientasi instrumental; memenangkan kliennya dalam kontestasi politik, bukan sepenuhnya dalam rangka beribadah. Dalam menjalankan praktiknya, Bunda terkesan 'memaksakan kehendak' kepada Tuhan, misalnya, dengan penggunaan istilah do'a yang 'dibayar kontan' (oleh Tuhan). Ia juga menggunakan sarana 'kurban 99 ekor ayam' sebagai instrumen transaksi dengan kekuatan yang bersifat adikodrati. Selain itu, Bunda juga menawarkan kepastian kemenangan melalui formula perbandingan antara suara yang ingin diraih dan jumlah pembaca zikir '1000:250'.

Kedekatan praktik Bunda dengan magi semakin jelas, jika merujuk pendapat Frazer (1958:56), bahwa ahli magi lebih dekat dengan ilmuwan daripada agamawan. Ahli magi dan ilmuwan menganggap rangkaian kejadian sebagai sesuatu yang pasti dan mengikuti aturan dengan sempurna, terbatasi oleh hukum-hukum yang tidak berubah, yang operasinya dapat diramalkan dan diperhitungkan dengan tepat. Praktik yang dijalankan oleh Bunda sebagai penasehat spiritual memiliki beberapa kesamaan dengan praktik yang dilakoni lembaga survei dan konsultan politik yang berpijak pada sains. Tahapan-tahapan zikir yang dilakukannya menyerupai tahapan-tahapan yang sering dilakukan lembaga survei, yaitu tahapan pemetaan (zikir mappateppe), tahapan peningkatan popularitas/elektabilitas (zikir hajat), dan tahapan survei prediksi akhir (zikir 'sapu mata').

\section{Kesimpulan}

Pranata politik modern yang mengagungkan pendekatan saintifik masih memberi ruang bagi hal-hal yang bersifat metafisika. Dalam kontestasi politik, sains menginstitusionalisasikan diri melalui lembaga survei dan konsultan politik, sedangkan aspek metafisika dipersonifikasikan oleh penasehat spiritual. Fenomena ini sekaligus membantah pembagian episteme zaman, dari Comte (2000:27-28) yang mengungkapkan bahwa zaman positivistik telah terjadi sejak tahun 1800 , sekaligus mengakhiri zaman teologis dan kosmologis. Zaman positivistik adalah era kejayaan sains, yang berdiri diatas pondasi rasionalisme dan empirisme. Penelitian ini menunjuk-kan bahwa manusia modern tetap memberi ruang bagi spiritualitas. Perkembangan ilmu pengetahuan dan teknologi, tidak sertamerta menyingkirkan peran sistem kepercayaan dalam pengambilan keputusan masyarakat modern.

Kesuksesan Bunda sebagai penasehat spiritual politik di era modern, tak bisa dipisahkan dengan kemampuannya mengintegrasikan agama, magi dan sains. Berbagai istilah yang menjadi konsen agama, seperti do'a, zikir, anak yatim, dan kurban, direproduksi untuk kepentingan branding produknya sebagai penasehat spiritual. Padahal sebenarnya produk tersebut adalah magi (baca Malinowski 1954 dan Frazer 1958). Demikian pula kemasan tahapan zikir, yang menyerupai tahapan survei, serta logika matematis '1000:250', menunjukkan upaya Bunda untuk membangun kesan saintifik. Konsekuensi ritual yang terukur meniscayakan biaya yang terukur pula. Itulah yang membuat Bunda berani memasang tarif Rp12,5 juta untuk seribu suara, serta biaya prediksi yang diklaim akurat (zikir 'sapu mata'), sebesar Rp77 juta.

\section{Daftar Pustaka}

Adams, Cindy., 2007. Soekarno Penyambung Lidah Rakyat Indonesia, Yogyakarta: Media Pressindo. 
Alhumami, Amich., 2009. Dukun dan Politik, http://www.bernardsimamora.com/dukundan-politik, diakses tanggal 3 Februari 2014.

Ardhianto, Imam., 2012. Hubungan Relasional dan Ontologi Moralitas: Meninjau Beberapa Tulisan Antropologi Mengenai Ritus Kurban, dalam Tony Rudiansjah (ed.),Antropologi Agama: Wacanawacana Mutakhir dalam Kajian Religi dan Budaya. Jakarta: UI Press, 109-126.

Baal, J. Van., 1987. Sejarah dan Pertumbuhan Teori Antropologi Budaya (Hingga Dekade 1970). Diterjemahkan oleh J. Piry. Jakarta: PT. Gramedia.

BPS., 2015. Sulawesi Selatan Dalam Angka 2015. Makassar: Badan Pusat Statistik Provinsi Sulawesi Selatan.

Bakti, Andi Faisal., 2007. Kekuasaan Keluarga di Wajo, Sulawesi Selatan, dalam Henk Schulte Nordholt, Gerry van Klinken, dan Ireen Karang-Hoogenboom (eds.) Politik Lokal di Indonesia, Jakarta: KITLV Jakarta dan Yayasan Obor Indonesia, 491505 .

Bennett, Linda R., 2005. Women, Islam and modernity: Single Women, Sexuality and Reproductive Health in Contemporary Indonesia. London and New York: Routledge Curzon.

Comte, Auguste., 2000. The Positive Philosophy, London: Batoche Books.

Eriksen, Thomas Hylland., 2009. Antropologi Sosial dan Budaya: Sebuah Pengantar. Maumere: Penerbit Ledalero.

Fahmid, Mujahidin., 2011. Pembentukan Elite Politik di dalam Etnis Bugis dan Makassar Menuju Hibriditas Budaya Politik.Disertasi. Bogor: Sekolah Pascasarjana Institut Pertanian.

Frazer, James. 1958.The Golden Bough (Abridged Edition). New York: Macmillan.

Geertz, Clifford., 1983. Abangan, Santri, Priyayi dalam Masyarakat Jawa. Jakarta: PT. Dunia Pustaka Jaya.

Goffman, Erving., 1959. The Presentation of Self in Everyday Life. New York: Double Day.

Halim, Abdul., 2014. Politik Lokal: Pola, Aktor dan Alur Dramatikalnya, Yogyakarta: LP2B.
Merdeka., 2013. Garansi Insya Allah Jadi, Dukun Politik Ngaku Keturunan Nabi,http:

//www.merdeka.com/peristiwa/garansiinsya-allah-jadi-dukun-politik-ngakuketurunan-nabi.html, diakses tanggal 9 Februari 2014.

Tribun Timur., 2013. Jimat Maccaleg Rp10 M, 23 Oktober, 17.

Haluan., 2012. Jelang Pilkada Dukun Laris, http://harianhaluan.com/index.php/khas/1 1782-jelang-pilkada-dukun-laris, diakses tanggal 3 Februari 2014.

Homans, George., 1974. Elementary Forms of Social Behavior. New York: Harcourt Brace Jovanovich.

Idrus, Nurul Ilmi., 2003. To Take Each Other: Bugis Practice of Gender, Sexuality and Marriage. Disertasi. Canberra: The Australian National University.

Malinowski, Bronislaw., 1948. Magi, Science and Religion, and Other Essays, Illinois: The Free Press.

Manguelle, Danielle Etounga., 2006. Perlukah Afrika Sebuah Program Penyesuaian Budaya?, dalam Lawrence E. Harrison dan Samuel P. Huntington (eds.) Kebangkitan Peran Budaya: Bagaimana Nilai-nilai Membentuk Kemajuan Manusia. Jakarta: LP3ES, 111-128.

Pelras, Christian., 2006. Manusia Bugis, Jakarta: Nalar kerjasama dengan Forum Jakarta Paris.

Peursen, C.A. Van., 1988. Strategi Kebudayaan, Yogyakarta: Kanisius.

Putra, Juma D., 2014. Dunia Batin 2 Macan Asia: Pengalaman-pengalaman Spiritual Bung Karno dan Pak Harto. Yogyakarta: Penerbit Palapa.

Pritchard, Evans., 1940. The Nuer: A Description of the Modes of Livehood and Political Institutions of a Nilotic People. Oxford: Clarendon Press.

Rakyat Sulsel., 2014. Jasa Paranormal Bayangi Para Caleg, 23 Februari, 1.

Roth, Dik., 2007. Gubernur Banyak, Provinsi Tak Ada: Berebut Provinsi di Daerah Luwu-Tana Toraja di Sulawesi Selatan, dalam Henk Schulte Nordholt dan Gerry van Klinken (eds.) Politik Lokal di Indonesia.Jakarta:KITLV Jakarta dan Yayasan Obor Indonesia, 154-189. 
Sahlan, Muhammad., 2010. "Dukun dan Politik": Peran Dukun Dalam Pemilukada di Banyuwangi Tahun 2010, http://etd.ugm.ac.id/index.php?mod=penel itian detail\&sub=PenelitianDetail\&act=vi ew\&typ $=$ html\&buku id $=58877$ \&obyek i $\mathrm{d}=4$, diakses tanggal 3 Februari 2014.

Said, Basir., 1996. Dukun, Suatu Kajian Sosial Budaya tentang Fungsi Dukun Bugis Makassar di Kotamadya Ujung Pandang. Tesis. Jakarta:Universitas Indonesia.

Syuhudi, Irfan., 2013. Etnografi Dukun: Studi Antropologi tentang Praktik Pengobatan Dukun di Kota Makassar. Tesis. Makassar: Program Pascasarjana Universitas Hasanuddin.
Solihat, Ade., 2012. Memahami Bahasa Agama dalam Perspektif Antropologi, dalam Tony Rudiansjah (ed.) Antropologi Agama: Wacana-wacana Mutakhir dalam Kajian Religi dan Budaya. Jakarta:UI Press, 6970.

Weber, Max., 2012. Sosiologi Agama: A Handbook. Diterjemahkan oleh Yudi Santoso. Yogyakarta: IRCiSoD. 